\title{
Synergistic action of cisplatin and echistatin in MDA-MB-231 breast cancer cells
}

\author{
Robert Czarnomysy ${ }^{1}$ (D) Arkadiusz Surażyński $^{2} \cdot$ Bożena Popławska $^{3} \cdot$ \\ Edyta Rysiak $^{2}$ - Natalia Pawłowska ${ }^{1}$ - Anna Czajkowska ${ }^{3} \cdot$ Krzysztof Bielawski $^{1}$. \\ Anna Bielawska ${ }^{3}$
}

Received: 23 June 2016/Accepted: 2 December 2016/Published online: 19 December 2016

(C) The Author(s) 2016. This article is published with open access at Springerlink.com

\begin{abstract}
The aim of our study was to determine whether the use of cisplatin in the presence echistatin in MDA-MB-231 breast cancer cells leads to a reduction of toxic effects associated with the use of cisplatin. The expression of $\beta_{1^{-}}$ integrin and insulin-like growth factor 1 receptor (IGF-IR), signaling pathway protein expression: protein kinase B (AKT), mitogen-activated protein kinases (ERK1/ERK2), nuclear factor kappa $\mathrm{B}(\mathrm{NF \kappa B})$, and caspase-3 and -9 activity was measured after $24 \mathrm{~h}$ of incubation with tested compounds to explain detailed molecular mechanism of induction of apoptosis. The viability of MDA-MB-231 breast cancer cells was determined by 3-(4,5-dimethylthiazol-2yl)-2,5-diphenyltetrazolium bromide assay. Annexin V-FITC/propidium iodide staining assay was performed to detect the induction of apoptosis. Inhibition DNA biosynthesis was determined by $\left[{ }^{3} \mathrm{H}\right]$ thymidine incorporation into DNA. The expression of of $\beta_{1}$-integrin, IGF-IR, AKT, ERK1/ERK2, NFKB, caspase-3 and -9 was evaluated using Western blot. The results suggest that treatment of MDAMB-231 breast cancer cells for $24 \mathrm{~h}$ cisplatin plus echistatin severely inhibits cell growth and activates apoptosis by upregulation of caspase- 3 and -9 expressions. The effect was stronger than treatment cisplatin and echistatin alone. In this study, we have found that cisplatin plus echistatin treatment
\end{abstract}

Robert Czarnomysy

robert.czarnomysy@umb.edu.pl

1 Department of Synthesis and Technology of Drugs, Medical University of Bialystok, Kilinskiego 1, 15-089 Bialystok, Poland

2 Department of Medicinal Chemistry, Medical University of Bialystok, Kilinskiego 1, 15-089 Bialystok, Poland

3 Department of Biotechnology, Medical University of Bialystok, Kilinskiego 1, 15-089 Bialystok, Poland decreases collagen biosynthesis in MDA-MB-231 breast cancer cells stronger than the individual compounds. The inhibition was found to be dependent on the $\beta_{1}$-integrin and IGF receptor activation. A significant reduction of ERK1/ ERK2, AKT expression in cancer cells after cisplatin plus echistatin treatment was also found. The cancer cells treated by echistatin, cisplatin, and in particular the combination of both compounds drastically increased expression of NFKB transcription factor. Our results suggest that combined therapy cisplatin plus echistatin is a possible way to improve selectiveness of cisplatin. This mechanism probably is due to downregulation of expression of $\beta_{1}$-integrin and IGF-IR receptors, and the signaling pathway proteins induced by these receptors. Our results suggest that therapy cisplatin plus echistatin is a possible way to improve selectiveness of cisplatin.

Keywords Breast cancer cells · Cisplatin - Echistatin . Apoptosis $\cdot$ Cell signaling

\section{Introduction}

Breast cancer is one of the most frequently diagnosed cancers in females [1]. Most cases of this disease occur in women at the age over 60. Despite significant progress toward understanding the mechanism of the disease, effective treatment is still lacking. The cornerstone treatment for numerous malignancies, including breast cancer is cisplatin [2]. Despite its success, the clinical usefulness of cisplatin is limited by its severe side effects such as neurotoxicity, myelosuppression, nephrotoxicity, and hepatotoxicity [3-6]. The need for alternatives to cisplatin has consequently inspired further work toward the development of novel platinum-based drugs or combined therapy 
with other components [7-11]. Combined therapy with e.g., anthracyclines, platinum compounds, and taxanes produces higher response rates, although combination regimens have not always improved survival rate. Doxorubicin plus cisplatin has been accepted as the Gynecologic Oncology Group standard regimen based on phase III clinical data [2].

Integrins are family of adhesive receptors that are responsible for recognition and adhesion of cells to extracellular matrix proteins [12]. The interaction between integrin receptors and extracellular matrix proteins, e.g., collagen is implicated in regulation of cellular gene expression, differentiation, and cell growth [13]. Integrin receptor signaling can play an important role in tumorigenicity and invasiveness [14]. Therefore, modulation of these receptors by disintegrins or intergin activators may represent potential strategy for cancer therapy. Disintegrin can interfere in important processes involved in carcinogenesis, tumor growth, invasion, and migration [15]. Additionally, in vivo co-administration disintegrins with cancer cells markedly inhibited tumor growth and bone destruction. Moreover, it has been shown that these proteins are capable to interact with specific integrins and to inhibit their activity [16]. These observations prompted the exploration of pharmacological blockade of integrins which was eventually demonstrated to significantly reduce tumor angiogenesis in numerous cancer models including breast cancer. Among of the breast cancer cell lines, most integrin receptors have MDA-MB-231 cell line. Other breast cancer cell lines are deficient phenotype of integrin receptors, e.g., MCF-7, MDA-MB-436, and MDA-MB-468 lack $\alpha 6 \beta 4$ integrin receptor [17].

The disintegrins ability to inhibit cell-matrix and cellcell interactions has been considered in many aspects. They were found to be the potent inhibitors of platelet aggregation, acting through the blockade of fibrinogen binding to platelet glycoprotein IIb/IIIa [18-21]. One of the main representatives of disintegrin is echistatin. It is known that echistatin as an inhibitor of $\beta_{1}$-integrin receptor contributes to inhibition of collagen biosynthesis and decrease in the expression of FAK (focal adhesion kinase), SOS-protein (son of sevenless protein), and phosphorylated MAP-kinases (mitogen-activated protein kinases), and ERK1 (extracellular signal-regulated kinase 1) and ERK2 (extracellular signal-regulated kinase 2) [18]. Stimulated $\beta_{1}$-integrin receptor induces autophosphorylation of nonreceptor protein kinase FAK, which is then capable of interacting with adaptor proteins, such as Grb2 (growth factor receptor bound protein 2), through $\mathrm{Src}$ and Shc proteins. This interaction allows activating further cascade of signaling pathway through SOS, Ras, and Raf proteins and subsequently, two MAP-kinases: ERK1 and ERK2. The end point of this cascade is induction of transcription factor(s) that regulate(s) gene expression of integrins, proteinases, and many proteins involved in the regulation of cell growth and differentiation [22-24].

The present study was undertaken to evaluate the effect of combined treatment of cisplatin plus echistatin on expression of some signaling proteins (EKR1/ERK2, AKT), transcription factors $(\mathrm{NF \kappa B})$, receptors $\left(\beta_{1}\right.$-integrin, IGF-I), as well on apoptosis and cell growth in MDA-MB-231 breast cancer cells. The results from combined treatment were compared with those obtained using monotherapy.

\section{Materials and methods}

\section{Chemical}

Cisplatin, echistatin, DMSO, 3-(4,5-dimethylthiazole-2-yl)2,5-diphenyltetrazolium bromide (MTT), sodium dodecyl sulfate (SDS) were provided by Sigma-Aldrich (USA). Stock culture of human MDA-MB-231 breast cancer was purchased from the American Type Culture Collection (USA). Dulbecco's minima essential medium (DMEM) and fetal bovine serum (FBS) used in a cell culture were products of Gibco (USA). Glutamine, penicillin, and streptomycin were obtained from QualityBiological Inc. (USA). [ [$\mathrm{H}]$ thymidine $(6.7 \mathrm{Ci} / \mathrm{mmol})$ were purchased from NEN (USA), and scintillation cocktail "Ultima GoldXR" from Packard (USA). FITC Annexin V Apoptosis Detection Kit was a product of BD Pharmigen (USA).

\section{Cell culture}

Human breast cancer MDA-MB-231 maintained in DMEM supplemented with $10 \%$ fetal bovine serum (FBS), 50 $\mathrm{U} / \mathrm{mL}$ penicillin, $50 \mu \mathrm{g} / \mathrm{mL}$ streptomycin at $37{ }^{\circ} \mathrm{C}$ in $5 \%$ $\mathrm{CO}_{2}$. Cells were cultured in Costar flasks, and subconfluent cells were detached with $0.05 \%$ trypsin and $0.02 \%$ EDTA in calcium-free phosphate buffer red saline, counted in hemocytometers, and plate at $5 \times 10^{5}$ cells/well of 6 -well plate (Nunc) in $2 \mathrm{~mL}$ of growth medium. Cells reached about $80 \%$ of confluency at day 3 , and most such cells were used for the assays.

\section{Cell viability assay}

The assay was performed according to the method of Carmichael et al. [25], using 3-(4,5-dimethylthiazole-2-yl)2,5-diphenyltetrazolium bromide (MTT). Confluent cells, cultured for $24 \mathrm{~h}$ with various concentrations of studied compounds in 6-well plates were washed three times with PBS and incubated for $4 \mathrm{~h}$ in $1 \mathrm{~mL}$ of MTT solution $\left(5 \mathrm{mg} / \mathrm{mL}\right.$ of $\mathrm{PBS}$ ) at $37{ }^{\circ} \mathrm{C}$ in $5 \% \mathrm{CO}_{2}$ in an incubator. The medium was removed and $1 \mathrm{~mL}$ of $0.1 \mathrm{~mol} / \mathrm{L} \mathrm{HCl}$ in 
absolute isopropanol was added to the attached cells. Absorbance of converted dye in living cells was measured at a wavelength of $570 \mathrm{~nm}$. Cell viability of breast cancer cells cultured in the presence of ligands was calculated as percent of control cells.

\section{Flow cytometry assessment of Annexin V binding}

Apoptosis was determined using the assessment of phosphatidylserine exposure by Annexin V-FITC binding by means of the Annexin V-FITC staining kit (FITC Annexin V Apoptosis Detection Kit, BD Pharmigen, USA) according to the manufacturer's instruction. Ungated cells (10,000 cells measured) were analyzed in a flow cytometer (FACSCanto II, BD, USA). Annexin V bound with affinity to phosphatidylserine and thus could be used to identify cells in all stages of the programmed cell death [26, 27]. Propidium iodide (PI) exclusively stained cells with a disrupted cell membrane and could be used to identify late apoptotic and dead cells. Cells were incubated with various concentrations of studied compounds for $24 \mathrm{~h}$. The cells were trypsinized and resuspended in DMEM. After that time, the cells were suspended in binding buffer for staining with FITC-Annexin $\mathrm{V}$ and PI for $15 \mathrm{~min}$ at room temperature in the dark, following the manufacturer's instructions. Cells cultured in a drug-free medium were used as controls. Optimal parameter settings were found using a positive control (cells incubated with $3 \%$ formaldehyde in buffer during $30 \mathrm{~min}$ on ice). Data were analyzed with FACSDiva software (BD Bioscences Systems, USA).

\section{$\left[{ }^{3} \mathbf{H}\right]$ thymidine incorporation assay}

Cells were seeded in 6-well plates and grown as described above. Cells culture were incubated with varying concentrations of echistatin, cisplatin, and $0.5 \mathrm{Ci} / \mathrm{mL}$ of $\left[{ }^{3} \mathrm{H}\right]$ thymidine for $4 \mathrm{~h}$ at $37{ }^{\circ} \mathrm{C}$. After that time, the cells surface was rinsed two times with $1 \mathrm{~mL}$ of $0.05 \mathrm{M}$ Tris$\mathrm{HCl}$ (pH 7.4) containing $0.1 \mathrm{M} \mathrm{NaCl}$ and two times with $1 \mathrm{~mL}$ of $5 \%$ TCA. Then the cells were lysed in $1 \mathrm{~mL}$ of $0.1 \mathrm{M} \mathrm{NaOH}$ containing $1 \%$ SDS. The cell lysate was added to $2 \mathrm{~mL}$ of scintillation liquid, and radioactivity incorporation into DNA was measured in a scintillation counter.

\section{5- $\left[{ }^{3} \mathbf{H}\right]$ proline incorporation assay}

Cells were labeled for $24 \mathrm{~h}$ with the $5-\left[{ }^{3} \mathrm{H}\right]$ proline $(5 \mu \mathrm{Ci}$ / $\mathrm{mL}, 28 \mathrm{Ci} / \mathrm{mmol})$. Its incorporation into proteins was measured as described previously [28]. Incorporation of the tracer into collagen was determined by digesting proteins with purified Clostridium histolyticum collagenase, according to the method of Peterkofsky et al. [29]. The results are shown as combined values for the cell plus medium fractions.

\section{Western blot analysis}

Samples of the lysates containing $25 \mu \mathrm{g}$ of protein were subjected to SDS-PAGE electrophoresis, as described by Laemmli [30]. Electrophoresis was run for 60 min using a $7.5 \%$ polyacrylamide gel, and constant current of $25 \mathrm{~mA}$ was applied. The resolved proteins were transferred to nitrocellulose membranes and pre-incubated with Tris-buffered saline (TBS) containing $0.05 \%$ Tween 20 (TBS-T) and $5 \%$ non-fat dry milk for $2 \mathrm{~h}$. Membranes were soaked in a mixture of monoclonal anti-phospho-IGF-I antibody (1:1000), monoclonal antibody $\beta_{1}$-integrin (1:1000), monoclonal anti-phospho-MAPK antibody (ERK1/ERK2) (1:1000), monoclonal anti-phospho-AKT antibody (1:1000), polyclonal NFאB antibody (1:1000), polyclonal caspase-9 antibody (1:1000), polyclonal caspase- 3 antibody (1:1000) in 5\% dried milk in Tris-buffered saline with Tween 20 (TBS-T). Next, $1 \mathrm{~h}$ incubation with secondary alkaline phosphatase-conjugated antibody against rabbit or mouse IgG at the 1:5000 dilution was carried out. Finally, the nitrocellulose membranes were washed five times with TBS$\mathrm{T}$ and exposed to Sigma-Fast BCIP/NBT reagent

\section{Statistical analysis}

All numerical data are presented as mean \pm standard deviation (SD) from at least three independent experiments. Statistical analysis was conducted using the Origin 7.5 software (OriginLab, USA). Statistical differences in multiple groups were determined by one-way ANOVA followed by Tukey's test. $p<0.05$ and $p<0.01$ were considered statistically significant.

\section{Results}

To evaluate cytotoxicity of echistatin, cisplatin, and cisplatin plus echistatin, the viability of breast cancer MDAMB-231 cells was measured by the method of Carmichael et al. [25]. Incubation of the cells for $24 \mathrm{~h}$ with disintegrin at concentrations 5,10 , and $50 \mathrm{ng} / \mathrm{mL}$ of medium had no significant effect on the cell viability (Fig. 1). Cisplatin at concentrations 25,50 , and $100 \mu \mathrm{M}$ induced the decrease of the cell viability to 90,78 , and $66 \%$ of control value, respectively (Fig. 1). However, incubation of MDA-MB231 cells with $10 \mathrm{ng} / \mathrm{mL}$ of echistatin with 25 or $50 \mu \mathrm{M}$ cisplatin decreased the cell viability to 85 and $52 \%$. Combination of those components decreased viability more effective than the cells were treated with disintegrin or cisplatin alone in the same concentration (Fig. 1). 
Fig. 1 Viability assay Carmichael et al. of MDA-MB231 breast cancer cells treated for $24 \mathrm{~h}$ with various concentrations of echistatin (E), cisplatin (cisPt), or cisplatin plus echistatin. Mean values \pm SD from three independent experiment $(n=3)$ done in duplicate are presented. ${ }^{*} p<0.05$ versus control group according to the method of

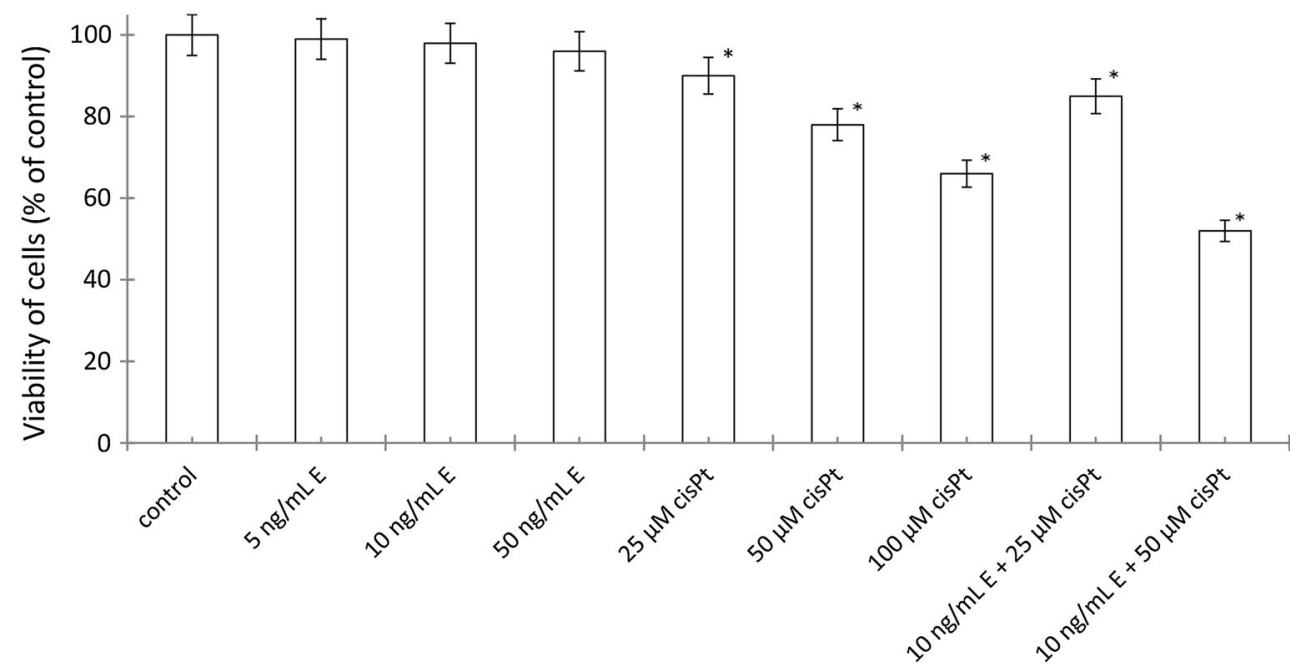

In order to evaluate whether echistatin, cisplatin, and cisplatin plus echistatin triggered apoptosis in the breast cancer cells, the cell death was measured by flow cytometer analysis after Annexin V-FITC and propidium iodide staining. The incubation of MDA-MB-231 cells with echistatin at concentrations 5,10 and $50 \mathrm{ng} / \mathrm{mL}$ of medium had no significant effect on the cell apoptosis (Fig. 2). Cisplatin at concentrations 25,50 , and $100 \mu \mathrm{M}$ induced increase of the cell apoptosis about 16.1, 24.6, and 39.1\% of control value, respectively. Incubation of MDA-MB-231 cells with $10 \mathrm{ng} / \mathrm{mL}$ of echistatin and 25 or $50 \mu \mathrm{M}$ cisplatin significantly increased the cell apoptosis after $24 \mathrm{~h}$ of treatment about 25.1 and $45.1 \%$ of control value (Fig. 2).

To further investigate the possible mechanism responsible for the growth inhibitory effects, we measured DNA synthesis in the presence of the disintegrin, cisplatin, and combination of these components. Echistatin had no significant effect on the DNA biosynthesis (Fig. 3). The incubation with cisplatin at concentration 25,50 , and $100 \mu \mathrm{M}$ decreased DNA biosynthesis about 91,82 , and $64 \%$ respectively. However, echistatin at concentration $10 \mathrm{ng} / \mathrm{mL}$ plus $50 \mu \mathrm{M}$ cisplatin significantly decreased DNA biosynthesis about $58 \%$ of control value (Fig. 3). Similar effect was observed in respect to collagen biosynthesis. The inhibition of the protein biosynthesis was the most effective when the cells were treated with $50 \mu \mathrm{M}$ cisplatin plus 10 ng/mL echistatin (Fig. 4).

Cell survival, adhesive, and protein biosynthesis (e.g., collagen) are regulated by the signal mediated by activated $\beta_{1}$-integrin and IGF-I receptors. The expression of the receptors was measured by Western immunoblot using specific antibodies. As shown in Fig. 5, cells with echistatin at concentrations 5,10 , and $50 \mathrm{ng} / \mathrm{mL}$ had no significant effect on the expression on IGF-IR. However, echistatin decreased $\beta_{1}$-integrin receptor in dose-dependent manner. Cisplatin at concentrations 25 and $50 \mu \mathrm{M}$ decreased expression on IGF-IR and had no effect on the
Fig. 2 Flow cytometer analysis of MDA-MB-231 breast cancer cells after incubation with of echistatin (E) and cisplatin (cisPt), or cisplatin plus echistatin for $24 \mathrm{~h}$ and subsequent staining with Annexin $\mathrm{V}$ and propidium iodide (PI). We presented representative dot plots form one of three independent experiments. Mean percentage values from three independent experiments $(n=3)$ done in duplicate are presented. ${ }^{*} p<0.05$ versus control group

expression on $\beta_{1}$-integrin receptor (Fig. 5). Incubation of MDA-MB-231 cells with $10 \mathrm{ng} / \mathrm{mL}$ of echistatin and 25 or $50 \mu \mathrm{M}$ cisplatin significantly decreases both receptors compare to control (Fig. 5).

ERK1/2 and AKT, induced by activated by $\beta_{1}$-integrin and IGF-I receptor, play a central role in carcinogenesis and tumor progression. As shown in Fig. 5, expression of both kinases ERK1/2 and AKT reflects expression of $\beta_{1^{-}}$ integrin and IGF-I receptor. Inhibition of those kinases may lead cells to activation of apoptosis.

We have found that cancer cells treated by echistatin, cisplatin, and in particular the combination of both compounds drastically increased expression of $\mathrm{NF \kappa B}$ transcription factor, responsible among other things for collagen inhibition and apoptosis (Fig. 5).

We found also that apoptosis induced by cisplatin plus echistatin is associated with activation of caspase- 9 and caspase-3, respectively. Both caspases are activated in dose-dependent manner for treatment echistatin or cisplatin. However, we observed a significant increase in expression of caspase-9 and -3 after the treatment with combination of both compounds, compared with these compounds either alone.

\section{Discussion}

Cisplatin is one of the most widely used and effective anticancer agents. It plays a major role in the treatment of a variety of cancers, including breast, ovarian, head and 


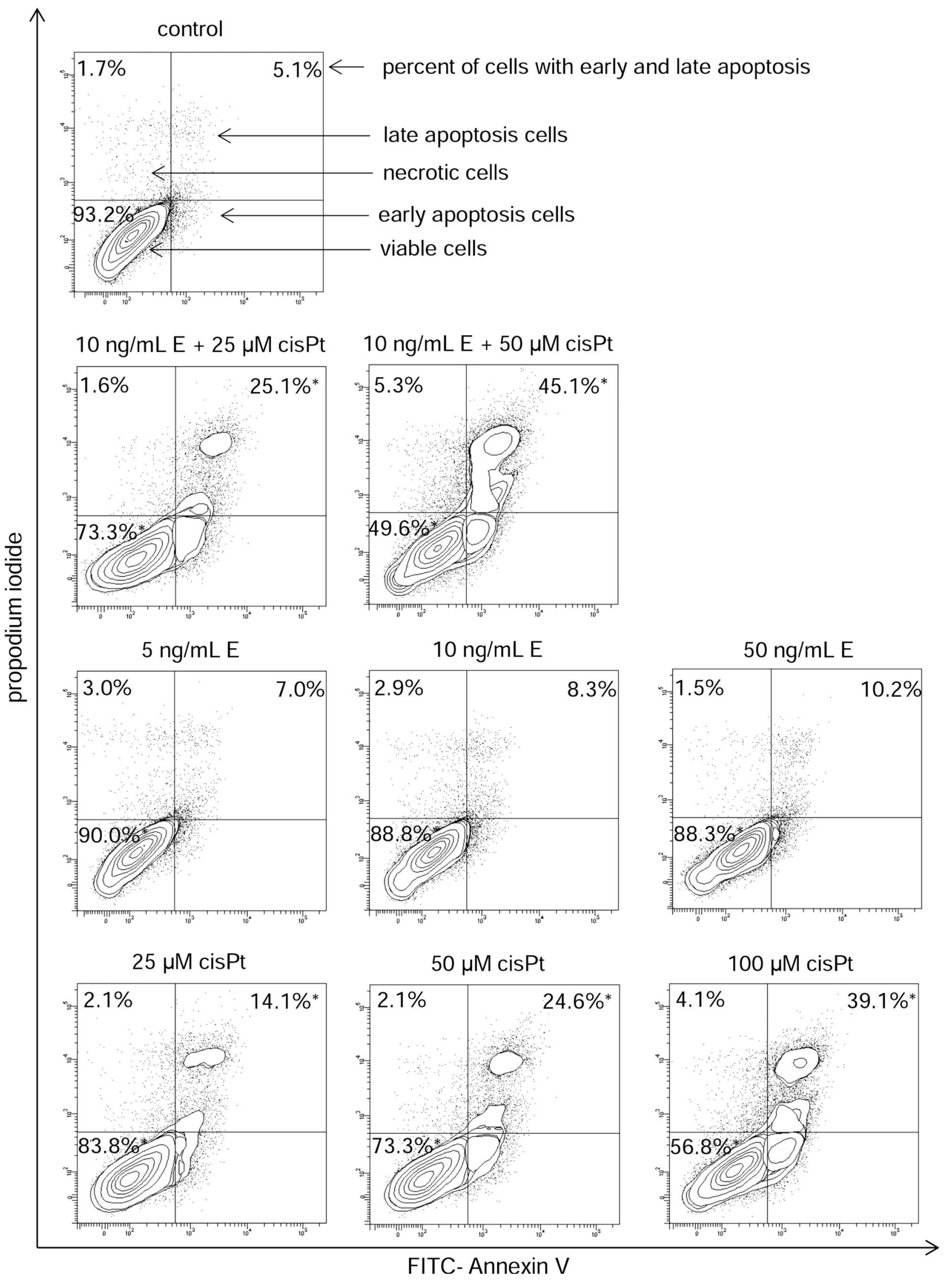


Fig. 3 DNA biosynthesis, measured by $\left[{ }^{3} \mathrm{H}\right]$-thymidyne incorporation into DNA in breast cancer cells MDA-MB231. Cells were incubated for $24 \mathrm{~h}$ with various concentrations of echistatin (E), cisplatin (cisPt), or cisplatin plus echistatin. Mean values \pm SD from three independent experiment $(n=3)$ done in duplicate are presented. $* p<0.05$ versus control group
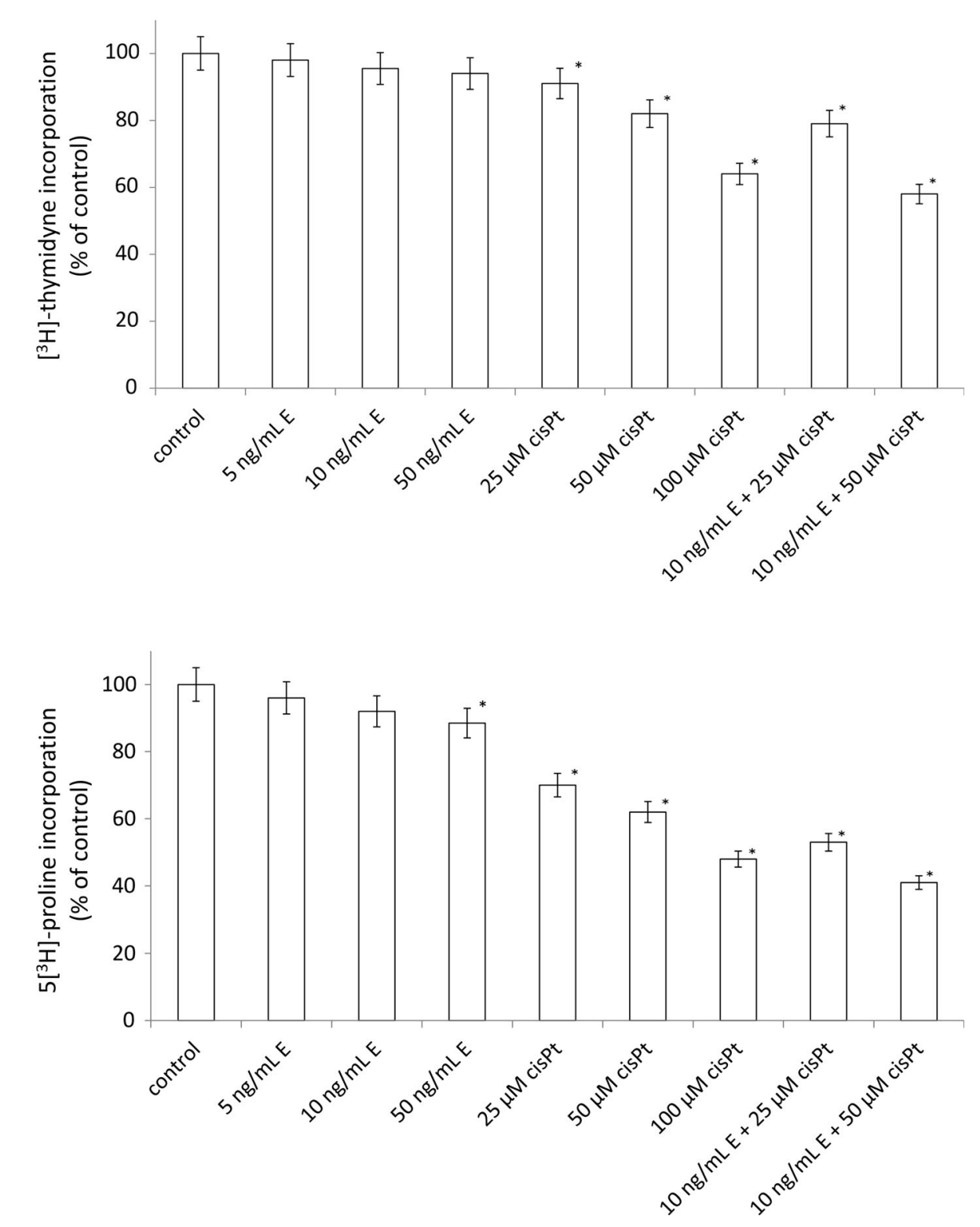

Fig. 4 Collagen biosynthesis measured as $5\left[{ }^{3} \mathrm{H}\right]$-proline incorporation into proteins susceptible to the action of bacterial collagenase in MDAMB-231 breast cancer cells incubated for $24 \mathrm{~h}$ with various concentrations of echistatin (E), cisplatin (cisPt), or cisplatin plus echistatin. Mean values \pm SD from three independent experiment $(n=3)$ done in duplicate are presented. ${ }^{*} p<0.05$ versus control group neck, cervical, lung, and colorectal cancer [31, 32]. The antitumor properties of cisplatin were discovered in the 60's by Rosenberg et al., and its clinical use was approved by the FDA in 1978. When DNA reacts with cisplatin, cross-linked adducts are produced, resulting in the distortion of its double-helix structure [33]. The efficacy of cisplatin in cancer treatment is often limited due to significant side effects and development of drug resistance. Combination of cisplatin with other drugs has been proven to be a successful therapeutic approach [3, 30]. Special emphasis has recently been given to the co-administration of cisplatin with drugs specifically targeting cancer cells $[34,35]$. For example, the combination of cisplatin and trastuzumab, an antibody raised against the EGF receptor subtype HER2, has shown promising clinical activity in patients with advanced breast cancer that overexpress
Fig. 5 Western immunoblot analysis for IGF-IR (A), $\beta_{1}$-integrin (B), AKT kinase $(\mathbf{C})$, ERK1/2 (D), NFKB $(\mathbf{E})$, caspase-9 $(\mathbf{F})$, caspase-3 $(\mathbf{G})$, and $\beta$-actin $(\mathbf{H})$ in subconfluent human breast cancer cells MDA-MB231 (control), cells treated with echistatin, cisplatin and cisplatin + echistatin for $24 \mathrm{~h}$. The intensity of the bands staining was quantified by densitometry analysis. ${ }^{*} p<0.05$ and $* p<0.01$ versus control group. 1 control, $25 \mathrm{ng} / \mathrm{mL}$ echistatin, $310 \mathrm{ng} / \mathrm{mL}$ echistatin, 4 $50 \mathrm{ng} / \mathrm{mL}$ echistatin, $525 \mu \mathrm{M}$ cisplatin, $650 \mu \mathrm{M}$ cisplatin, $710 \mathrm{ng} / \mathrm{mL}$ echistatin $+25 \mu \mathrm{M}$ cisplatin, $810 \mathrm{ng} / \mathrm{mL}$ echistatin $+50 \mu \mathrm{M}$ cisplatin. Samples used for electrophoresis consisted of $25 \mu \mathrm{g}$ protein of pooled cell extracts. $A U$ arbitrary units, $I G F-I R$ insulin-like growth factor 1 receptor, $A K T$ protein kinase $\mathrm{B}, E R K$ extracellular signal-regulated kinase, $N F \kappa B$ nuclear factor kappa B

HER2 [34, 35]. The addition of bevacizumab, a monoclonal antibody against vascular endothelial growth factor (VEGF), to platinum-based chemotherapy resulted in an improved response and survival in patients with non-small 

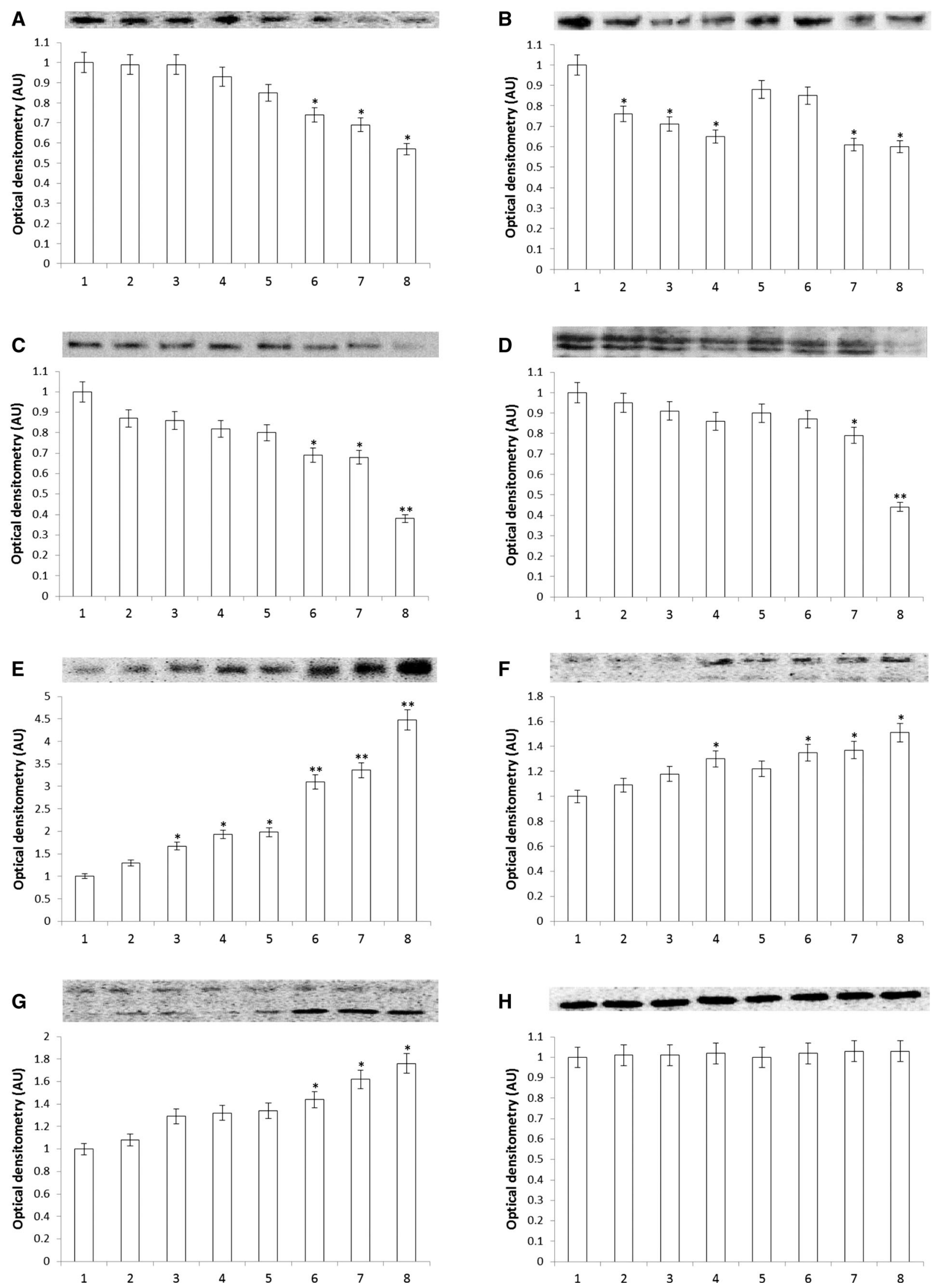
cell lung cancer. Moreover, selenium and cisplatin interact on the same intracellular toxic cascade, and the combination of these two drugs can result in a remarkable anticancer effect through modulation of the TRPV1 [36].

Echistatin and other disintegrins have been extensively studied in the past. It is now established that disintegrins are effective agents in limiting tumor growth and spread $[19,20]$. Disintegrins interacting with several integrins block various integrin-mediated processes involved in tumor growth, metastasis, and angiogenesis [21]. The integrins family is responsible for adhesion of cells to extracellular matrix components as well as to other cells [12]. The interaction affects cytoskeleton organization, lipid metabolism, kinase activation, gene expression [37], cell cycle progression [38], and metastasis [39]. Integrins $\beta_{1}$ and $\beta_{3}$ play also an important role in tumor invasion [40]. Cell migration, invasion, matrix degradation, proliferation, and angiogenesis are all mediated by integrins and integrin signaling effects on DNA biosynthesis [41, 42]. Moreover, the previous studies have reported that disintegrins may be reduced the protection of cancer cells from apoptosis [43]. In recent years, combined treatment of conventional anticancer agents with natural compounds (like disintegrins) has been a focus of study due to the fact that natural compounds are multi-targeted compared with designed mono-target agents and hence can overcome intrinsic cancer cell resistance to apoptosis [44]. As shown by studies of lung cancer therapy, a combined treatment with disintegrin caused a greater apoptotic effect than in its absence [45]. The same conclusions regarding combination therapy with disintegrin presented the researchers in the case hepatocellular carcinoma [46]. We found that cisplatin plus echistatin increases the sensitivity of MDA-MB-231 breast cancer cells to death through an apoptotic mechanism as compared to the use cisplatin alone. The apoptotic effect due to treatment breast cancer cells with cisplatin plus echistatin required low doses of those reagents which were compared with those obtained using monotherapy.

The higher cytotoxicity of combined treatment is also associated with a significant inhibition of DNA biosynthesis. The functional significance of the treatment of MDA-MB-231 breast cancer cells cisplatin plus echistatin was found also at the level of collagen biosynthesis. Our findings are consistent with the previous work which demonstrated that combination therapy with cytostatic agents from the group of alkylating agents and echistatin, produces a greater decrease in collagen biosynthesis than treatment with the alkylating drug alone [47]. Decreased amount of collagen in extracellular matrix may facilitate motility and invasion of neoplastic cells, but also may suppress cell growth and induce of apoptosis [48] as confirmed our results.
The previous studies have shown that IGF-I receptor signaling and $\beta_{1}$-integrin receptor are involved in signaling that regulates collagen biosynthesis $[49,50]$. Prokop et al. suggest that IGFBP-1 (IGF binding protein 1) may affect collagen biosynthesis through downregulation of signal generated by the integrin receptor. An addition of IGF-BP1 to the medium of cultured fibroblasts contributed to decrease in collagen biosynthesis. The same effect was achieved by echistatin- $\beta_{1}$-integrin blocker [51]. The endometrial cancer cells treated for $24 \mathrm{~h}$ with melphalan and disintegrin showed decreased expression of IGF receptor in comparison to the cells treated with both compounds separately [47]. Our study showed that treatment cisplatin plus echistatin inhibited expression of that receptor more than cisplatin alone. IGF-IR is involved in regulation of cellular growth and transformation [52]. Therefore, inhibition of the receptor expression may represent approach to the inhibition of tumor growth. Blockade of the receptor [53] or downregulation of its expression [54] reduces cancer proliferation and induces apoptosis. Decreased expression of the receptor by cisplatin plus echistatin could explain decreased biosynthesis of collagen in the cells, since IGF-IR is a most potent inducer of collagen biosynthesis [55].

$\mathrm{NF \kappa B}$ is also responsible for the inhibition of collagen gene expression [56]. It is well known that NFKB affects not only the regulation of a number of genes associated with the modulation of apoptosis, but also genes responsible for immune response, encoding proteins that regulate cell proliferation or inflammation $[57,58]$. NFKB regulates the transcription genes involved in cell differentiation, proliferation, and apoptosis [56]. One of the factors strongly stimulate the expression of $\mathrm{NF \kappa B}$ is cisplatin $[7,59]$. In the present study, we observed an interesting effect that echistatin in combination with cisplatin to a greater extent induces expression of $\mathrm{NF} \kappa \mathrm{B}$ than cisplatin. In the case of the simultaneous presence of echistatin and cisplatin increase, NFKB correlates with an increase number of apoptotic cells. It may be one of the factors which direct tumor cells to apoptosis.

The NFkB signaling cascade interacts with several parallel pathways including the signaling cascades initiated by phosphatidylinositol 3-kinase (PI3K) and AKT [60]. The AKT and MAPK are main signaling molecules correlated with the activation of the p53 pathways in different cells and tissue types [61]. AKT is known as a signaling inductor of cell survival acting through upregulation of anti-apoptotic proteins. Simultaneously, a family of serinethreonine protein kinases, MAPKs, plays significant roles in relation to the p53 pathway in different cancer cells [62]. ERKs also play key roles in cell growth and survival and are generally overexpressed in many cancer cell types [61]. Different studies have demonstrated that the anticancer 
effect of anticancer drugs like trastuzumab, tamoxifen, doxorubicin, and paclitaxel involved an inhibition of the MAPK and PI3K/AKT resulting in a p53-mediated apoptosis $[63,64]$. In our study, the synergistic effect on cisplatin plus echistatin a much greater blocked the extracellular signal-regulated kinase (ERK1/ERK2) and AKT in MDA-MB-231 cell than cisplatin or echistatin alone in the same concentrate. Combination of cisplatin and echistatin induces increase of the expression of $\mathrm{NF} \kappa \mathrm{B}$ and decrease of the expression of AKT leads to increase apoptosis, what we observed in our study.

\section{Conclusions}

Our results suggest that therapy cisplatin plus echistatin is a possible way to improve selectiveness of cisplatin. These results indicate that the use cisplatin plus echistatin may constitute a new strategy in chemotherapy of breast cancer.

Acknowledgements This research was supported by Medical University of Bialystok (Grant Nos. N/ST/ZB/16/002/2217 and N/ST/ $\mathrm{ZB} / 16 / 003 / 2217)$. This study was conducted with the use of equipment purchased by Medical University of Bialystok as part of the OP DEP 2007-2013, Priority Axis I.3, Contract No. POPW.01.03.00-20022/09.

\section{Compliance with ethical standards}

Conflict of interest The authors declare that they have no conflict of interest.

Open Access This article is distributed under the terms of the Creative Commons Attribution 4.0 International License (http://crea tivecommons.org/licenses/by/4.0/), which permits unrestricted use, distribution, and reproduction in any medium, provided you give appropriate credit to the original author(s) and the source, provide a link to the Creative Commons license, and indicate if changes were made.

\section{References}

1. Desantis C, Siegel R, Bandi P, Jemal A (2011) Breast cancer statistics 2011. CA Cancer J Clin 61(6):409-418

2. Obel JC, Friberg G, Fleming GF (2006) Chemotherapy in endometrial cancer. Clin Adv Hematol Oncol 4(6):459-468

3. Hartmann JT, Fels LM, Knop S, Stolt H, Kanz L, Bokemeyer C (2000) A randomized trial comparing the nephrotoxicity of cisplatin/ifosfamide-based combination chemotherapy with or without amifostine in patients with solid tumors. Investig New Drugs 18:281-289

4. Hartmann JT, Lipp HP (2003) Toxicity of platinum compounds. Expert Opin Pharmacother 4(6):889-901

5. Iraz M, Ozerol E, Gulec M, Tasdemir S, Idiz N, Fadillioglu E, Naziroglu M, Akyol O (2006) Protective effect of caffeic acid phenethyl ester (CAPE) administration on cisplatin-induced oxidative damage to liver in rat. Cell Biochem Funct 24:357-361

6. Naziroglu M, Karaoglu A, Aksoy AO (2004) Selenium and high dose vitamin $\mathrm{E}$ administration protects cisplatin-induced oxidative damage to renal, liver and lens tissues in rats. Toxicology 195:221-230

7. Bielawska A, Popławska B, Surażyński A, Czarnomysy R, Bielawski K (2010) Cytotoxic efficacy of a novel dinuclear platinum(II) complex in human breast cancer cells. Eur J Pharmacol 643:34-41

8. Bielawski K, Bielawska A, Popławska B, Surażyński A, Czarnomysy R (2010) The effect of a novel dinuclear platinum complex with berenil and 2-picoline ligands on growth of human breast cancer cells. Acta Pol Pharm 67:609-614

9. Bielawski K, Czarnomysy R, Muszyńska A, Bielawska A, Popławska B (2013) Cytotoxicity and induction of apoptosis of human breast cancer cells by novel platinum(II) complexes. Environ Toxicol Pharmacol 35(2):254-264

10. Czarnomysy R, Bielawska A, Muszyńska A, Bielawski K (2015) Effects of novel alkyl pyridine platinum complexes on apoptosis in Ishikawa endometrial cancer cells. Med Chem 11(6):540-550

11. Czarnomysy R, Bielawski K, Muszynska A, Bielawska A, Gornowicz A (2016) Biological evaluation of dimethylpyridineplatinum complexes with potent antiproliferative activity. J Enzyme Inhib Med Chem 4:1-16

12. Hanks SK, Calalb MB, Harper MC, Patel SK (1992) Focal adhesion protein-tyrosine kinase phosphotylated in response to cell attachment to fibronectin. Proc Natl Acad Sci USA 89(18):8487-8491

13. Niu G, Chen X (2011) Why integrin as a primary target for imaging and therapy. Theranostics 1:30-47

14. Hamidi H, Pietilä M, Ivaska J (2016) The complexity of integrins in cancer and new scopes for therapeutic targeting. Br J Cancer 115(9):1017-1023

15. Arruda Macêdo JK, Fox JW, de Souza Castro M (2015) Disintegrins from snake venoms and their applications in cancer research and therapy. Curr Protein Pept Sci 16(6):532-548

16. Yang RS, Tang CH, Chuang WJ, Huang TH, Peng HC, Huang $\mathrm{TF}, \mathrm{Fu}$ WM (2005) Inhibition of tumor formation by snake venom disintegrin. Toxicon 45(5):661-669

17. Gordon LA, Mulligan KT, Maxwell-Jones H, Adams M, Walker RA, Jones JL (2003) Breast cell invasive potential relates to the myoepithelial phenotype. Int J Cancer 106(1):8-16

18. Surazyński A, Sienkiewicz P, Wołczyński S, Pałka J (2005) Differential effects of echistatin and thrombin on collagen production and prolidase activity in human dermal fibroblasts and their possible implication in $\beta_{1}$-integrin-mediated signaling. Pharmacol Res 51(3):217-221

19. Zhou Q, Sherwin RP, Parrish C, Richters V, Groshen SG, TsaoWei D, Markland FS (2000) Contortrostatin, a dimeric disintegrin from Agkistrodon contortrix contortrix, inhibits breast cancer progression. Breast Cancer Res Treat 61:249-260

20. Ritter MR, Zhou Q, Markland FS Jr (2000) Contortrostatin, a snake venom disintegrin, induces alphavbeta3-mediated tyrosine phosphorylation of CAS and FAK in tumor cells. J Cell Biochem 79:28-37

21. Swenson S, Costa F, Minea R, Sherwin RP, Ernst W, Fujii G, Yang D, Markland FS Jr (2004) Intravenous liposomal delivery of the snake venom disintegrin contortrostatin limits breast cancer progression. Mol Cancer Ther 3(4):499-511

22. Juliano R (1996) Cooperation between soluble factors and integrin mediated cell anchorage in the control of cell growth and differentiation. BioEssays 18(11):911-917

23. Seger R, Krebs EG (1995) The MAPK signaling cascade. FASEB J 9(9):726-735

24. Labat-Robert J, Robert L (2000) Interaction between cells and extracellular matrix: signaling by integrins and the elastin-laminin receptor. Prog Mol Subcell Biol 25:57-70

25. Carmichael J, DeGraff WG, Gazdar AF, Minna JD, Mitchell JB (1987) Evaluation of a tetrazolium-based semiautomated 
colorimetric assay: assessment of chemosensitivity testing. Cancer Res 47(4):943-946

26. Westermann B (2008) Molecular machinery of mitochondrial fusion and fission. J Biol Chem 283(20):13501-13505

27. Vermes I, Haanen C, Steffens-Nakken H, Reutelingsperger C (1995) A novel assay for apoptosis. Flow cytometric detection of phosphatidylserine expression on early apoptotic cells using fluorescein labeled Annexin V. J Immunol Methods 184(1):39-51

28. Oyamada I, Pałka JA, Schalk EM, Takeda K, Peterkofsky B (1990) Scorbutic and fasted guinea pig sera contain an insulinlike growth factor I reversible inhibitor of proteoglycan and collagen synthesis in chick embryo chondrocytes and adult human skin fibroblasts. Arch Biochem Biophys 276(1):85-93

29. Peterkofsky B, Palka J, Wilson S, Takeda K, Shah V (1991) Elevated activity of low molecular weight insulin-like growth factor-binding proteins in sera of vitamin C-deficient and fasted guinea pigs. Endocrinology 128(4):1769-1779

30. Laemmli UK (1970) Cleavage of structural proteins during the assembly of the head of bacteriophage T4. Nature 227(5259):680-685

31. Lebwohl D, Canetta R (1998) Clinical development of platinum complexes in cancer therapy: an historical perspective and an update. Eur J Cancer 34(10):1522-1534

32. Galanski M (2006) Recent developments in the field of anticancer platinum complexes. Recent Pat Anticancer Drug Discov 1(2):285-295

33. Kartalou M, Essigmann JM (2001) Recognition of cisplatin adducts by cellular proteins. Mutat Res 478:1-21

34. Pegram MD, Pienkowski T, Northfelt DW, Eiermann W, Patel R, Fumoleau P, Quan E, Crown J, Toppmeyer D, Smylie M, Riva A, Blitz S, Press MF, Reese D, Lindsay MA, Slamon DJ (2004) Results of two open-label, multicenter phase II studies of docetaxel, platinum salts and trastuzumab in HER2-positive advanced breast cancer. J Natl Cancer Inst 96(10):759-769

35. Hurley J, Doliny P, Reis I, Silva O, Gomez-Fernandez C, Velez P, Pauletti G, Powell JE, Pegram MD, Slamon DJ (2006) Docetaxel, cisplatin, and trastuzumab as primary systemic therapy for human epidermal growth factor receptor 2-positive locally advanced breast cancer. J Clin Oncol 24(12):1831-1837

36. Sakallı Çetin E, Nazıroğlu M, Çiğ B, Övey İS, Aslan Koşar P (2016) Selenium potentiates the anticancer effect of cisplatin against oxidative stress and calcium ion signaling-induced intracellular toxicity in MCF-7 breast cancer cells: involvement of the TRPV1 channel. J Recept Signal Transduct Res 8:1-10

37. Meredith JE Jr, Winitz S, Artur Lewis J, Hess S, Xiang-Dong R, Renshaw MW, Schwartz MA (1996) The regulation of growth and intracellular signaling by integrins. Endocr Rev 17(3):207-220

38. Adams JC (2001) Cell-matrix contact structures. Cell Mol Life Sci 58(3):371-392

39. Bosco M, Chan C, Matsuura N, Tokada Y, Zetter BR, Hemler ME (1991) In vitro and in vivo consequences of VLA-2 expression on rhabdomyosarcoma cells. Science 251(5001):1600-1602

40. Kramer RH, Vu M, Cheng YF, Ramos DM (1991) Integrin expression in malignant melanoma. Cancer Metastasis Rev 10:49-59

41. Giancotti FG, Mainiero F (1994) Integrin-mediated adhesion and signaling in tumorigenesis. Biochim Biophys Acta 1198(1):47-64

42. Varner JA, Cheresh DA (1996) Integrins and cancer. Curr Opin Cell Biol 8(5):724-730

43. Tsagaraki I, Tsilibary EC, Tzinia AK (2010) TIMP-1 interaction with $\alpha v \beta 3$ integrin confers resistance to human osteosarcoma cell line MG-63 against TNF- $\alpha$-induced apoptosis. Cell Tissue Res 342(1):87-96

44. Vyas VK, Brahmbhatt K, Bhatt H, Parmar U (2013) Therapeutic potential of snake venom in cancer therapy: current perspectives. Asian Pac J Trop Biomed 3(2):156-162

45. Chang L, Gong F, Cai H, Li Z, Cui Y (2016) Combined RNAi targeting human Stat3 and ADAM9 as gene therapy for non-small cell lung cancer. Oncol Lett 11(2):1242-1250
46. Liu S, Zhang W, Liu K, Wang Y, Ji B, Liu Y (2014) Synergistic effects of co-expression plasmid-based ADAM10-specific siRNA and GRIM-19 on hepatocellular carcinoma in vitro and in vivo. Oncol Rep 32(6):2501-2510

47. Miltyk W, Surażyński A, Wołczyński S, Pałka JA (2009) Combined therapy with disintegrin and melphalan as a new strategy in inhibition of endometrial cancer cell line (Ishikawa) growth. Folia Histochem Cytobiol 47(5):121-125

48. Boudreau N, Bissel MJ (1998) Extracellular matrix signaling: integration of form and function in normal and malignant cells. Curr Opin Cell Biol 10:640-646

49. Karna E, Miltyk W, Surazynski A, Pałka J (2008) Protective effect of hyaluronic acid on interleukin-1-induced deregulation of $\beta_{1}$-integrin and insulin-like growth factor-I receptor signaling and collagen biosynthesis in cultured human chondrocytes. Mol Cell Biochem 308:57-64

50. Surażyński A, Pałka J, Wołczyński S (2004) Acetylsalicylic aciddependent inhibition of collagen biosynthesis and $\beta_{1}$-integrin signaling in cultured fibroblasts. Med Sci Monit 10(6):175-179

51. Prokop I, Konończuk J, Surażyński A, Pałka J (2013) Cross-talk between integrin receptor and insulin-like growth factor receptor in regulation of collagen biosynthesis in cultured fibroblasts. Adv Med Sci 58(2):292-297

52. Baserga R, Hongo A, Rubini M, Prisco M, Valentinis B (1997) The IGF-I receptor in cell growth, transformation and apoptosis. Biochem Biophys Acta Rev Cancer 1332:105-106

53. Maloney EK, McLaughlin JL, Dagdigian NE, Garrett LM, Connors KM, Zhou XM, Blättler WA, Chittenden T, Singh R (2003) An antiinsulin-like growth factor I receptor antibody that is a potent inhibitor of cancer cell proliferation. Cancer Res 63:5073-5083

54. Xie SP, Pirianov G, Colston KW (1999) Vitamin D analogues suppress IGF-I signaling and promote apoptosis in breast cancer cells. Eur J Cancer 35:1717-1723

55. Goldstein RH, Poliks CF, Plich PF, Smith BD, Fine A (1989) Stimulation of collagen formation by insulin-like growth factor-I in cultures of human lung fibroblasts. Endocrinology 124:964-970

56. Miltyk W, Karna E, Palka J (2007) Prolidase independent mechanism of camptothecin - induced inhibition of collagen biosynthesis in cultured human skin fibroblasts. J Biochem 141(2):287-292

57. Bharti AC, Aggarwal BB (2002) Nuclear factor-kappa B and cancer: its role prevention and therapy. Biochem Pharmacol 64:883-888

58. Garg A, Aggarwal BB (2002) Nuclear transcription factor- $\kappa \mathrm{B}$ as target for cancer drug development. Leukemia 16:1053-1068

59. Chtourou Y, Aouey B, Kebieche M, Fetoui H (2015) Protective role of naringin against cisplatin induced oxidative stress, inflammatory response and apoptosis in rat striatum via suppressing ROS-mediated NF- $\mathrm{BB}$ and p53 signaling pathways. Chem Biol Interact 5(239):76-86

60. Bai D, Ueno L (2009) Vogt PK (2009) Akt-mediated regulation of NFKB and the essentialness of NFKB for the oncogenicity of PI3K and Akt. Int J Cancer 125(12):2863-2870

61. Tanel A, Averill-Bates DA (2007) p38 and ERK mitogen-activated protein kinases mediate acrolein-induced apoptosis in Chinese hamster ovary cells. Cell Signal 19(5):968-977

62. Eisele G, Weller M (2013) Targeting apoptosis pathways in glioblastoma. Cancer Lett 332(2):335-345

63. Clark AS, West K, Streicher S, Dennis PA (2002) Constitutive and inducible Akt activity promotes resistance to chemotherapy, trastuzumab, or tamoxifen in breast cancer cells. Mol Cancer Ther 1(9):707-717

64. Diarra-Mehrpour M, Arrabal S, Jalil A, Pinson X, Gaudin C, Piétu G, Pitaval A, Ripoche H, Eloit M, Dormont D, Chouaib S (2004) Prion protein prevents human breast carcinoma cell line from tumor necrosis factor alpha-induced cell death. Cancer Res 64(2):719-727 